\title{
Study of Ceria-Carbonate Nanocomposite Electrolytes for Low-Temperature Solid Oxide Fuel Cells
}

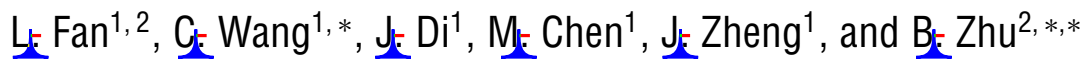 \\ ${ }^{1}$ Key Laboratory for Green Chemical Technology of Ministry of Education, School of Chemical Engineering \\ and Technology, Tianjin University, Tianjin 300072, P. R. China \\ ${ }^{2}$ Department of Energy Technology, Royal Institute of Technology, Stockholm S-100 44, Sweden
}

\begin{abstract}
Composite and nanocomposite samarium doped ceria-carbonates powders were prepared by solidstate reaction, citric acid-nitrate combustion and modified nanocomposite approaches and used as electrolytes for low temperature solid oxide fuel cells. X-ray Diffraction, Scanning Electron Microscope, low-temperature Nitrogen Adsorption/desorption Experiments, Electrochemical Impedance Spectroscopy and fuel cell performance test were employed in characterization of these materials. All powders are nano-size particles with slight aggregation and carbonates are amorphous in composites. Nanocomposite electrolyte exhibits much lower impedance resistance and higher ionic conductivity than those of the other electrolytes at lower temperature. Fuel cell using the electrolyte prepared by modified nanocomposite approach exhibits the best performance in the whole operation temperature range and achieves a maximum power density of $839 \mathrm{~mW} \mathrm{~cm}^{-2}$ at $600{ }^{\circ} \mathrm{C}$ with $\mathrm{H}_{2}$ as fuel. The excellent physical and electrochemical performances of nanocomposite electrolyte make it a promising candidate for low-temperature solid oxide fuel cells.
\end{abstract}

Keywords: Low-Temperature Solid Oxide Fuel Cells, Doped Ceria-Carbonate, Electrolyte, Nanocomposite, Electrochemical Performance.

\section{INTRODUCTION}

Solid oxide fuel cells (SOFCs) have attracted great attention in recent years because of their distinct advantages such as high thermodynamic efficiently, environmentally benign and fuel flexibility. ${ }^{1}$ However, SOFCs operating at high temperatures $\left(800-1000{ }^{\circ} \mathrm{C}\right)$ present materials degradation problems and economic obstacles. ${ }^{2}$ Considerable efforts have been made to decrease the operating temperature $\left(<600{ }^{\circ} \mathrm{C}\right)$ while maintaining reasonable electrochemical performance to utilize the following advantages: $:^{3,4}$ (1) wildly materials selection for cell components; (2) quickly start-up and shut-down; (3) significantly enhancement of the components stability and system lifetime; (4) simplified materials synthesis and cell manufacture processes and (5) low cost to make more marketable competition. Unfortunately, the traditional electrolyte, yttria-stabilized zirconia (YSZ), shows insufficient ionic conductivity at low temperature. Therefore, kinds of electrolytes have been developed. For example, doped ceria, $\mathrm{La}_{0.9} \mathrm{Sr}_{0.1} \mathrm{Ga}_{0.8} \mathrm{Mg}_{0.2} \mathrm{O}_{3}$ (LSGM) and zirconia and yttria co-doped $\mathrm{BaCeO}_{3 \pm \delta}$ (BZCY). Among them, Boped ceria-based electrolytes are the most

\footnotetext{
*Authors to whom correspondence should be addressed
}

promising alternative materials and have been considered good candidates for low-temperature application. However, the inherent drawback of the electronic conduction caused by the reduction of $\mathrm{Ce}^{4+}$ to $\mathrm{Ce}^{3+}$ at lower oxygen partial pressure and elevated temperature has become a barrier for their further application. ${ }^{5}$ Additionally, the electrochemical performance of low-temperature SOFCs with ceriabased electrolytes still need to be improved. ${ }^{6}$ Hence, new advanced material design and functionality developments to solve these problems are still big challenges.

Different composite electrolytes are developed in recent years based on doped ceria and the second phases like salt $^{7-11}$ and oxide ${ }^{12}$ for low temperature SOFCs. Compared to the traditional electrolytes, these double phase composite electrolytes show many merits, such as high ionic conductivity $\left(>0.1 \mathrm{~S} \mathrm{~cm}^{-1}\right.$ below $\left.600{ }^{\circ} \mathrm{C}\right),{ }^{9}$ hybrid $\mathrm{O}^{2-} / \mathrm{H}^{+}$co-conduction, ${ }^{10,13}$ effectively suppression of the electronic conduction ${ }^{10}$ and high electrochemical performance $\left(>1 \mathrm{~W} \mathrm{~cm}^{-2}\right.$ at $600{ }^{\circ} \mathrm{C}$ with $\mathrm{H}_{2}$ as fuel). ${ }^{13}$ These interesting properties of composite electrolytes have shown great potential application in low temperature SOFCs.

Furthermore, nanocomposties for advanced fuel cell technology (NANOCOFC) have been proposed to develop low temperature SOFCs. The electrolytes and electrode materials explored based on the nanocomposite concept 
exhibited unique ionic conduction properties and high redox reaction activities. ${ }^{14-18}$ However, the fundamental study of the low temperature SOFCs is still in its infancy and the intense work are needed to advance their practical application. Additionally, SOFCs with composite and nanocomposite electrolytes have been studied extensively, but their performances vary widely depending on the experimental conditions ${ }^{9,10,13,15,19}$ and few works are coverd to compare the performance of composite and nanocomposite electrolytes for low temperature SOFCs. ${ }^{20}$ Hence, in this study, composite and nanocomposite electrolytes were prepared by three methods: solid state reaction, citric acid-nitrate combustion and modified nanocomposite approach. They are investigated in term of their crystal structures, morphologies, electrical conductivities and current-voltage and current-power density characteristics with Ni-based electrodes in the same test condition. The results presented herein highlight the promising application of nanocomposite electrolyte in low temperature SOFCs.

\section{EXPERIMENTAL DETAILS}

\subsection{Electrolyte Powders Preparation}

$\mathrm{Sm}_{0.2} \mathrm{Ce}_{0.8} \mathrm{O}_{1.9}$ (SDC)-carbonate composite and nanocomposite electrolytes were prepared by three methods: solid state reaction (SR), citric acid-nitrate combustion (CN) and modified nanocomposite approach (NANO). The eutectic carbonates in this study are the mixture of $\mathrm{Li}_{2} \mathrm{CO}_{3}$ and $\mathrm{Na}_{2} \mathrm{CO}_{3}$ with a molar ratio of $52: 48$ and sintered at $500{ }^{\circ} \mathrm{C}$ for $30 \mathrm{~min}$.

\subsubsection{Solid State Reaction Method}

$\mathrm{Ce}\left(\mathrm{NO}_{3}\right)_{3} \cdot 6 \mathrm{H}_{2} \mathrm{O}$ was calcined at $500{ }^{\circ} \mathrm{C}$ for $30 \mathrm{~min}$, then the resulted powders were mixed with $\mathrm{Sm}_{2} \mathrm{O}_{3}$ and dispersed in deionic water by ball milling for $5 \mathrm{~h}$. The mixture was dried overnight at $100{ }^{\circ} \mathrm{C}$. After that it was calcined at $700{ }^{\circ} \mathrm{C}$ for $2 \mathrm{~h}$ to obtain the composite precursor SDC. The sintered eutectic carbonates and SDC (weight ratio 1:4) were mixed with ethanol by ball milling for $2 \mathrm{~h}$. After dried in an oven at $80{ }^{\circ} \mathrm{C}$, the mixture was sintered at $680{ }^{\circ} \mathrm{C}$ for $40 \mathrm{~min}$ and cooled in air directly. The resulted powder was crushed and named as SR-SCC.

\subsubsection{Citric Acid-Nitrate Combustion Method}

The composite electrolyte prepared by citric acid-nitrate combustion method was described in our previous report ${ }^{10}$ and the synthesized powders were named as CN-SCC.

\subsubsection{Modified Nanocomposite Method}

In our work, the nanocomposite electrolyte was prepared by the modified NANOCOFC approach. ${ }^{15}$ Firstly,
$\mathrm{Ce}\left(\mathrm{NO}_{3}\right)_{3} \cdot 6 \mathrm{H}_{2} \mathrm{O}$ and $\mathrm{Sm}\left(\mathrm{NO}_{3}\right)_{3} \cdot 6 \mathrm{H}_{2} \mathrm{O}$ was mixed with a molar ratio of $4: 1$ to form nitrate solution. Secondly, the nitrate solution was precipitated by the $\mathrm{Na}_{2} \mathrm{CO}_{3}$ solution $(0.5 \mathrm{M})$. The molar ratio metal ion/ $\mathrm{CO}_{3}{ }^{2-}$ is $1: 2$. The resulting white suspended solution was stirred violently for $2 \mathrm{~h}$. an amount of $\mathrm{Li}_{2} \mathrm{CO}_{3}$ was then added and stirred for another $2 \mathrm{~min}$ before the suspended solution was filtered and dried in air overnight at $80{ }^{\circ} \mathrm{C}$. Finally, the prepared powders were sintered at $800{ }^{\circ} \mathrm{C}$ for $2 \mathrm{~h}$. The resultant powders were named as NANO-SCC.

\subsection{Characterizations}

The crystal structures of three types of electrolytes were identified by X-ray diffraction (XRD) at room temperature with a D/max $2500 \mathrm{v} / \mathrm{pc}$ instrument (Rigaku Corp. Japan) using $\mathrm{Cu} \mathrm{K} \alpha$ radiation $(\lambda=1.5406 \AA)$. The specific surface areas of these electrolytes were calculated by the multiple points Brunauer-Emmett-Teller method with the low temperature nitrogen adsorption/desorption experiments performed with a Quantachrome Autosorb-1 analyzer at $-196{ }^{\circ} \mathrm{C}$. The morphologies of electrolytes were observed with a scanning electron microscope (SEM, JSM-6700F, JEOL Ltd., Japan). For electrical conductivity measurements, the prepared electrolytes were drypressed under $300 \mathrm{MPa}$ to obtain green plates. Each side of the green plates was coated with silver paste and sintered at $650{ }^{\circ} \mathrm{C}$ for $30 \mathrm{~min}$. The final thickness of the plates was about $1 \mathrm{~mm}$. The electrical conductivity was obtained by the AC electrochemical impedance spectroscope (EIS) analyses performed on an electrochemical workstation (PARSTAT 2273, Princeton Applied Research, USA) in air with the applied frequencies in the range of $100 \mathrm{kHz}$ to $0.1 \mathrm{~Hz}$ with amplitude of $10 \mathrm{mV}$ between $300{ }^{\circ} \mathrm{C}$ and $600{ }^{\circ} \mathrm{C}$.

\subsection{Electrochemical Performance}

The anode was a mixture of $\mathrm{NiO}(55 \mathrm{wt} \%)$ and SCC (45 wt \%). The cathode consisted of SCC (45 wt $\%$ ) and lithiated $\mathrm{NiO}(55 \mathrm{wt} \%)$ prepared by solid-state reaction. ${ }^{19}$ The composite anode, electrolyte and composite cathode powders were successively loaded in a stainless steel die (13 $\mathrm{mm}$ in diameter) and dry-pressed to form a sandwich green plate under $300 \mathrm{MPa}$. Both sides of the plates were coated with silver paste and sintered in air $600{ }^{\circ} \mathrm{C}$ for $30 \mathrm{~min}$. The thicknesses of the anode, electrolyte and cathode after sintered are about $500 \mu \mathrm{m}, 300 \mu \mathrm{m}$ and $200 \mu \mathrm{m}$, respectively. Cell performances of these fabricated fuel cells were measured by a computerized instrument (L-43, Tianjin, China) in a range of $450-600{ }^{\circ} \mathrm{C}$ with humidified $\mathrm{H}_{2}$ and flow air as fuel and oxidant, respectively. The gas flow rates were controlled in the range of $80-100 \mathrm{~mL} \mathrm{~min}^{-1}$. The active areas were about $0.785 \mathrm{~cm} .^{2}$ 


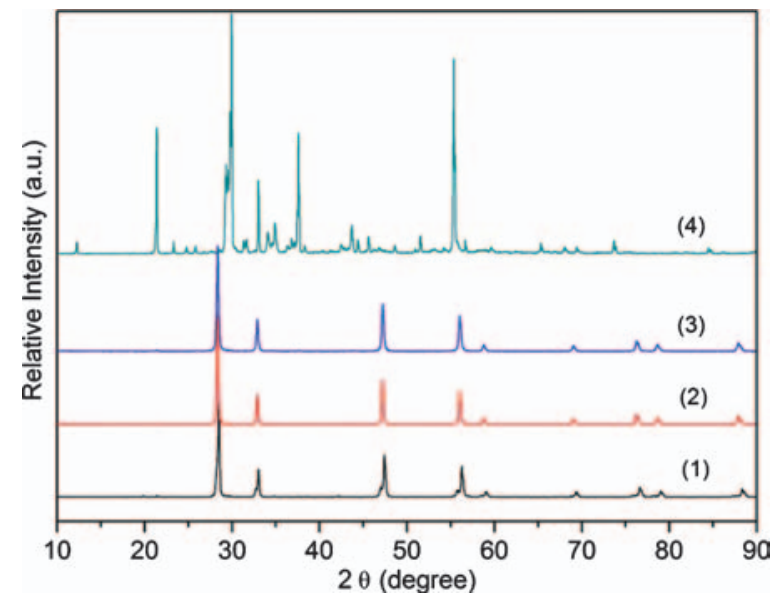

Fig. 1. XRD patterns of the prepared powders: (1) SR-SCC, (2) CNSCC, (3) NANO-SCC and (4) the eutectic carbonates after sintered at $500{ }^{\circ} \mathrm{C}$ for $30 \mathrm{~min}$.

\section{RESULTS AND DISCUSSION}

The XRD patterns of three-type of electrolytes are shown in Figure 1. The pattern of the eutectic carbonates of $\mathrm{Li}_{2} \mathrm{CO}_{3}$ and $\mathrm{Na}_{2} \mathrm{CO}_{3}$ before mixed with $\mathrm{SDC}$ is also presented. It can be seen that the main peaks in $\mathrm{CN}$ SCC, SR-SCC and NANO-SCC are corresponding to $\mathrm{Sm}_{0.2} \mathrm{Ce}_{0.8} \mathrm{O}_{1.9}$ (JCPDS 75-0158), and no peak for carbonates is observed indicating that the carbonates are amorphous in all electrolytes. ${ }^{10}$ The average crystallize sizes of SR-SCC, CN-SCC and NANO-SCC estimated by the Scherrer equation are about 42, 34 and $25 \mathrm{~nm}$, respectively.

The morphologies of prepared electrolytes are given in Figure 2. All electrolytes' surfaces are homogenously covered by the carbonates and no distinct interfaces between SDC and carbonates can be detected. As can be seen from Figure 2, the NANO-SCC powders show smaller particle
Table I. The specific surface areas of the prepared composite electrolytes.

\begin{tabular}{lccc}
\hline Sample & SR-SCC & CN-SCC & NANO-SCC \\
\hline Surface Area $\left(\mathrm{m}^{2} \mathrm{~g}^{-1}\right)$ & 1.6 & 2.2 & 4.7 \\
\hline
\end{tabular}

size and better dispersion than SR-SCC and CN-SCC powders. Besides, all electrolytes consist of aggregated crystallites after sintered. According to the low temperature nitrogen adsorption/desorption experiments, the specific surface area of SR-SCC, CN-SCC and NANO-SCC is determined to be 1.6, 2.2 and $4.7 \mathrm{~m}^{2} \mathrm{~g}^{-1}$ as shown in Table I, respectively. All prepared electrolytes still keep relative high special surface area after sintered, though the molten carbonates in the composites may reduce the surface area significantly.

AC electrochemical impedance spectroscopy (EIS) measurements are carried out in air from $300{ }^{\circ} \mathrm{C}$ to $600{ }^{\circ} \mathrm{C}$. The typical impedance spectra at $500{ }^{\circ} \mathrm{C}$ are illustrated in Figure 3. The inserted picture is the magnified photo of the partial EIS curves of NANO-SCC and CN-SCC. The measured EIS data have been corrected by the thickness of the plates. The impedance curves of NANO-SCC and SR-SCC consist of a depressed arc related to electrochemical electrode response and a tail corresponding to mass transfer process. ${ }^{10}$ However, the impedance curve of $\mathrm{CN}-\mathrm{SCC}$ contains two overlapped arcs and a tail; the grain boundary effect may involve in the high frequency arc. It should be noted that the impedance resistance of NANOSCC at $500{ }^{\circ} \mathrm{C}$ is significantly lower than that of SR-SCC and $\mathrm{CN}-\mathrm{SCC}$, which is considered to be contributed by the large amount of surfaces and interface. ${ }^{20}$

The intercepts values of the impedance spectra curves with the real-axis can be used to calculate the electrical conductivities. The temperature dependence of the electrical conductivities for prepared electrolytes is displayed
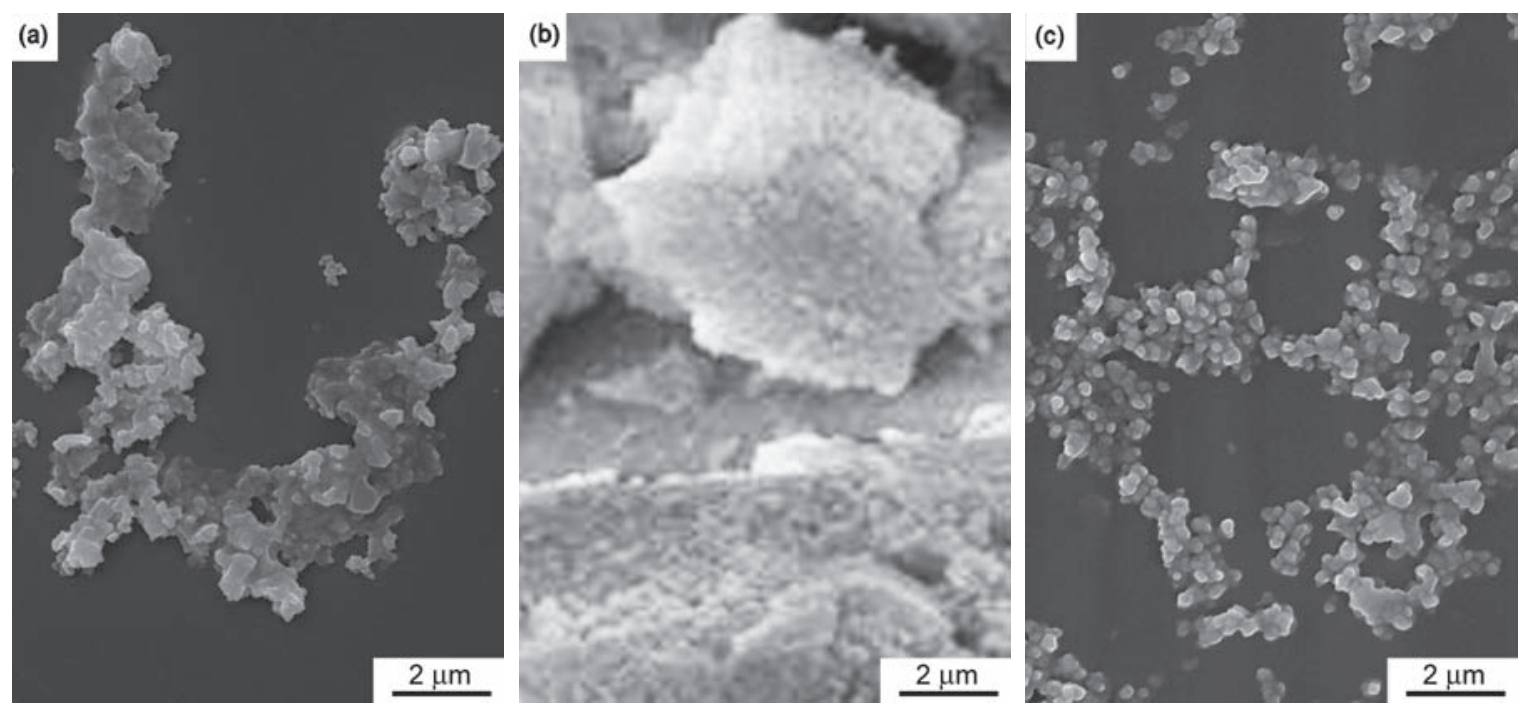

Fig. 2. SEM images of prepared electrolytes: (a) SR-SCC, (b) CN-SCC and (c) NANO-SCC. 


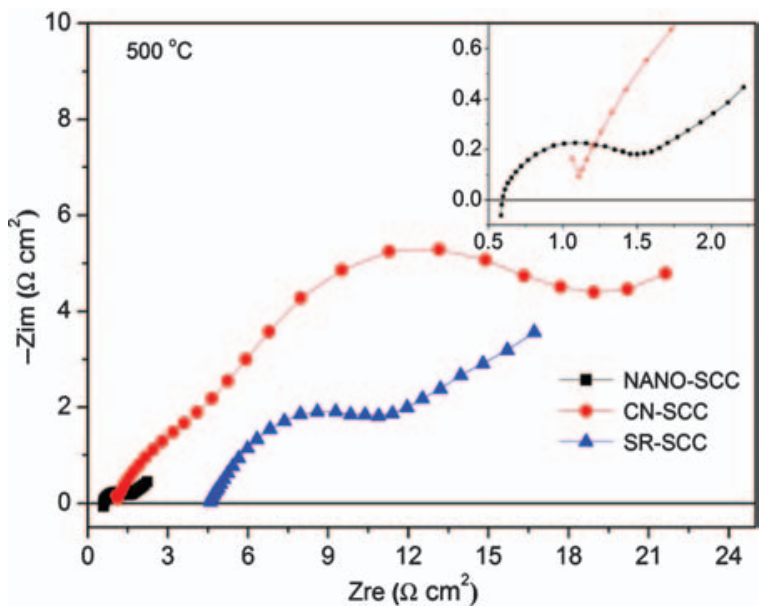

Fig. 3. Typical AC impedance spectra for various electrolytes in air at $500{ }^{\circ} \mathrm{C}$.

in Figure 4; the conductivity of pure SDC is also included for comparison. For NANO-SCC, the conductivities are much higher than that of SDC in the whole temperature range. However, duo to the ionic block effect of the carbonates, ${ }^{21}$ the conductivities of SR-SCC and CN-SCC electrolytes are lower than pure SDC conductivity when the temperature is less than a critical values, $450{ }^{\circ} \mathrm{C}$ and $350{ }^{\circ} \mathrm{C}$ for SR-SCC and CN-SCC, respectively. In addition, as can be seen from Figure 4, A discontinues in conductivity of SR-SCC and CN-SCC can be seen at a certain temperature. Similar behaviors have also been reported with the same composite system, ${ }^{13}$ which is interpreted as superionic phase transitions in the interface phases. However, the phase transition temperatures of SR-SCC, $\mathrm{CN}-\mathrm{SCC}$ and composite electrolyte in the literature ${ }^{13}$ are different even using the same material composition. These behaviors may relate to the various interfacial properties. Nevertheless, there is no distinct leap for the conductivity curve of NANO-SCC at the operating temperature range.

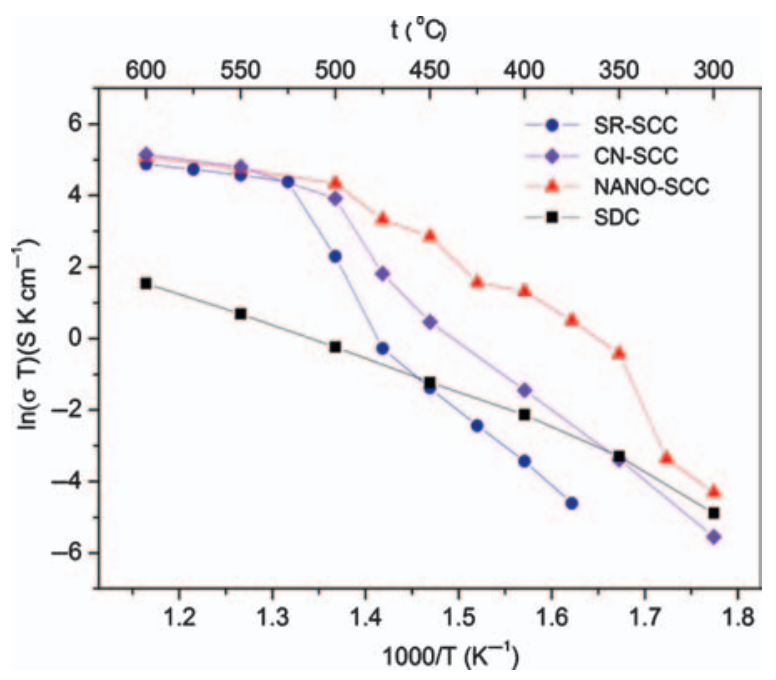

Fig. 4. Temperature dependence of the electrical conductivity curves.
More importantly, electrical conductivity of NANO-SCC is much higher than that of SR-SCC and CN-SCC below $500{ }^{\circ} \mathrm{C}$. In the previously works, many facts demonstrated that the interfacial conductivity takes up mainly part of the total ionic conductivity. ${ }^{17,22,23}$ Therefore, the conducting behaviors discrepancies of these prepared electrolytes may reveal the difference of nano-SDC surface and interface properties.

To compare the performances of prepared electrolytes, fuel cells were constructed and tested with Ni-based electrodes from $450{ }^{\circ} \mathrm{C}$ to $600{ }^{\circ} \mathrm{C}$ in real fuel cell condition. I-V and I-P characteristics of single cells are shown in Figure 5. For all the fabricated fuel cells, the open circuit voltages (OCVs) are higher than $0.96 \mathrm{~V}$ and decrease
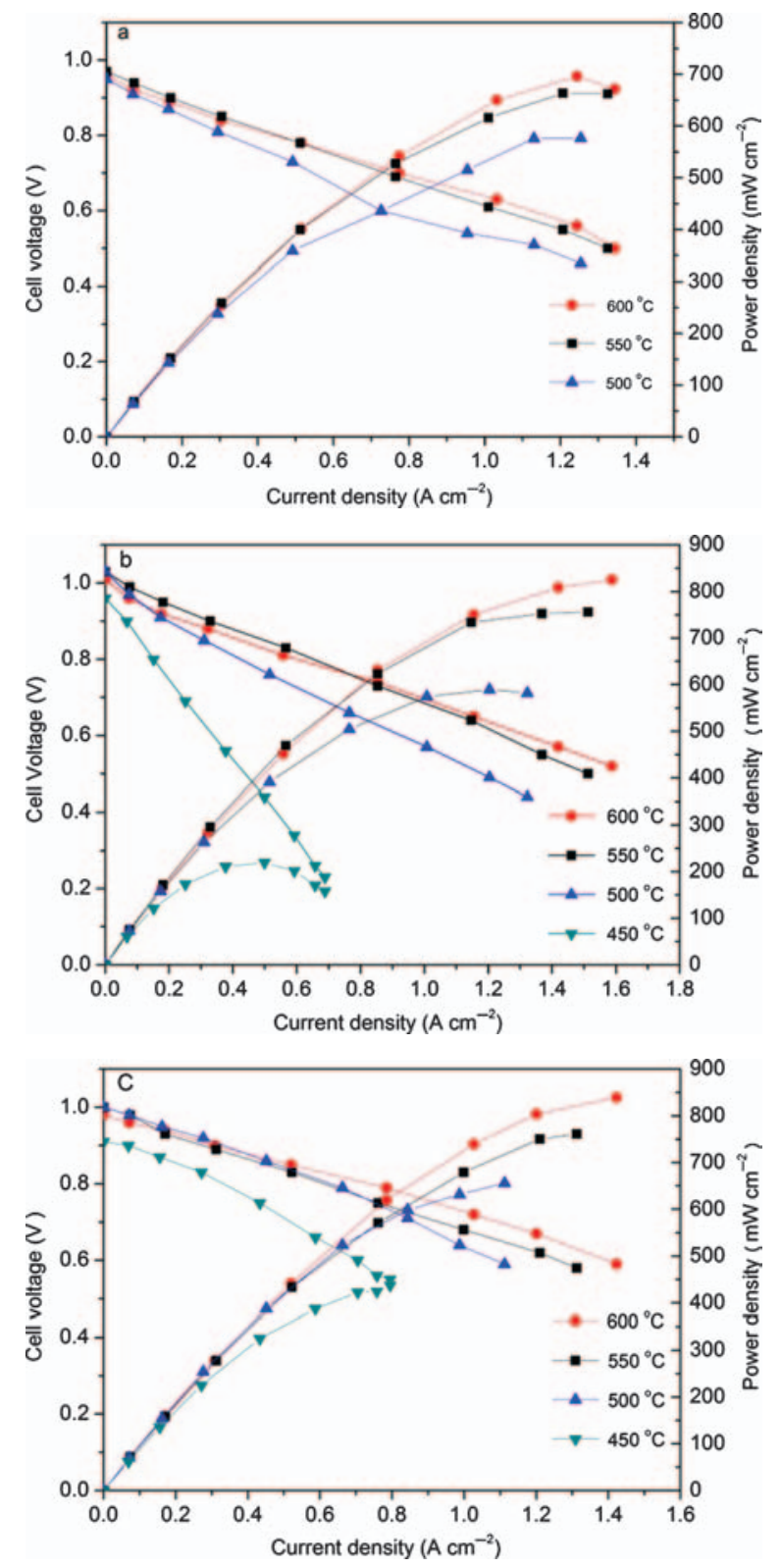

Fig. 5. I-V and I-P characteristics of single cells using (a) SR-SCC, (b) CN-SCC and (c) NANO-SCC as electrolytes at various temperatures.

J. Nanosci. Nanotechnol. 12, 1-5, 2012 
as operation temperatures increase between $500{ }^{\circ} \mathrm{C}$ and $600{ }^{\circ} \mathrm{C}$, indicating that all electrolytes in fuel cell are gastight in this temperature range. Besides, OCVs are much higher than these of SDC-based fuel cells, ${ }^{24}$ where the OCVs never reach $0.89 \mathrm{~V}$ when the temperature is above $500{ }^{\circ} \mathrm{C}$. The high OCVs demonstrate that the existing of carbonates can effectively suppress the reduction of $\mathrm{Ce}^{4+}$ to $\mathrm{Ce}^{3+}$ thus remove the electronic conduction at fuel cell condition. According to I-P characteristics, the maximum power densities generated at $600{ }^{\circ} \mathrm{C}$ were 696,825 and $839 \mathrm{~mW} \mathrm{~cm}^{-2}$ using SR-SCC, CN-SCC and NANO-SCC electrolytes, respectively. The good fuel cell performances should mainly be attributed to high ionic conductivity of composite and nanocomposite electrolytes. In addition, single cell with NANO-SCC electrolyte exhibits the best performance among all fuel cells in the whole operating temperature range. Especially, a maximum output of $437 \mathrm{~mW} \mathrm{~cm}^{-2}$ was obtained using NANO-SCC electrolyte at $450{ }^{\circ} \mathrm{C}$, which is almost twice of fuel cell performance with $\mathrm{CN}-\mathrm{SCC}$ electrolyte. The excellent performance of the cells with NANO-SCC electrolyte at low temperature is attributed to the highest ionic conductivity of the nanocomposite electrolyte. As mentioned above, the small particle size and the homogeneous distribution of SDC and carbonates in NANO-SCC electrolyte will produce large SDC surface and interface that provide more paths for ion transportation. That is, the lowest electrolyte ohmic resistance conduces to the best fuel cell performance using nanocomposite electrolyte.

\section{CONCLUSIONS}

In this work, the performances of different composite and nanocomposite electrolytes were investigated for low temperature solid oxide fuel cell. Nanocomposite electrolyte with small particle size, homogeneous distribution of the particles exhibits lower (interfacial) impedance resistance, higher ionic conductivity than those of other composite electrolytes. Fuel cell using nanocomposite electrolyte achieves the highest power densities of 839.5 and $437.2 \mathrm{~mW} \mathrm{~cm}^{-2}$ for $600{ }^{\circ} \mathrm{C}$ and $450{ }^{\circ} \mathrm{C}$, respectively. The high electrochemical performance of nanocomposite electrolyte, especially at low temperature, should be contributed to the large surface and interface between SDC and carbonates. The results indicate that nanocomposite samarium doped ceria-carbonates is a great potential electrolyte for the new generation low temperature SOFC.
Acknowledgments: Funding from VINNOVA (Swedish Agency for Innovation Systems) is highly acknowledged. Liangdong Fan is thankful to a joint $\mathrm{PhD}$ program between KTH and TJU and also appreciates CSC (China Scholarship Council) for support to study at Royal Institute of Technology.

\section{References and Notes}

1. S. C. Singhal, Solid State Ionics 152,405 (2002).

2. N. P. Brandon, S. Skinner, and B. C. H. Steele, Annu. Rev. Mater. Res. 33, 183 (2003).

3. Q. L. Liu, K. A. Khor, and S. H. Chan, J. Power Sources 161, 123 (2006).

4. J. Akikusa, K. Adachi, K. Hoshino, T. Ishihara, and Y. Takita, J. Electrochem. Soc. 148, A1275 (2001)

5. X. Zhang, M. Robertson, C. Deces-Petit, W. Qu, O. Kesler, R. Maric, and D. Ghosh, J. Power Sources 164, 668 (2007).

6. R. Doshi, V. Richards, J. Carter, X. Wang, and M. Krumpelt, J. Electrochem. Soc. 146, 1273 (1999).

7. B. Zhu, J. Power Sources 114, 1 (2003).

8. B. Zhu, X. T. Yang, J. Xu, Z. G. Zhu, S. J. Ji, M. T. Sun, and J. C. Sun, J. Power Sources 118, 47 (2003).

9. X. Wang, Y. Ma, R. Raza, M. Muhammed, and B. Zhu, Electrochem. Commun. 10, 1617 (2008).

10. J. Di, M. Chen, C. Wang, J. Zheng, L. Fan, and B. Zhu, J. Power Sources 195, 4695 (2010).

11. B. Zhu, X. Liu, Z. Zhu, and R. Ljungberg, Int. J. Hydrogen Energy 33, 3385 (2008).

12. B. Zhu, X. R. Liu, and T. Schober, Electrochem. Commun. 6, 378 (2004).

13. J. Huang, Z. Mao, Z. Liu, and C. Wang, Electrochem. Commun. 9, 2601 (2007).

14. R. Raza, X. Wang, Y. Ma, and B. Zhu, J. Power Sources 195, 8067 (2010).

15. R. Raza, X. Wang, Y. Ma, X. Liu, and B. Zhu, Int. J. Hydrogen Energy 35, 2684 (2010).

16. R. Raza, X. Wang, Y. Ma, and B. Zhu, J. Power Sources 195, 6491 (2010).

17. R. Raza, Y. Ma, X. D. Wang, X. R. Liu, and B. Zhu, J. Nanosci. Nanotechnol. 10, 1203 (2010).

18. Q. Liu and B. Zhu, Appl. Phys. Lett. 97, 183115 (2010).

19. J. Huang, L. Yang, R. Gao, Z. Mao, and C. Wang, Electrochem. Commun. 8, 785 (2006).

20. Z. Tang, Q. Lin, B.-E. Mellander, and B. Zhu, Int. J. Hydrogen Energy 35, 2970 (2010)

21. J. Huang, Z. Gao, and Z. Mao, Int. J. Hydrogen Energy 35, 4270 (2010).

22. C. Xia, Y. Li, Y. Tian, Q. H. Liu, Z. M. Wang, L. J. Jia, Y. C. Zhao, and Y. D. Li, J. Power Sources 195, 3149 (2010).

23. S. Li, X. D. Wang, and B. Zhu, Electrochem. Commun. 9, 2863 (2007).

24. Y. Ji, J. Liu, T. He, L. Cong, J. Wang, and W. Su, J. Alloys Compd. 353, 257 (2003).

Received: 1 December 2010. Accepted: 1 May 2011. 